\title{
The genus Rinodina in the Kuril Islands (Russian Far East)
}

\author{
I. A. Galanina' ${ }^{1}$ A. K. Ezhkin ${ }^{2}$ \\ ' Federal Scientific Center of East Asian Terrestrial Biodiversity, Far Eastern Branch of the Russian Academy of Sciences, \\ 100-let Vladivostoku str., 159, Vladivostok, 690024, Russian Federation. E-mail: gairka@yandex.ru \\ ${ }^{2}$ Institute of Marine Geology and Geophysics FEB RAS, Nauki str., 1B, Yuzhno-Sakhalinsk, 693022, Russian Federation. \\ E-mail:ezhkin@yandex.ru \\ *Corresponding author: gairka@yandex.ru
}

Keywords: biodiversity, disjunctive distribution, lichens, new species, northeast Asia, Physciaceae.

Summary. The presented work is based on the study of extensive material collected by Ezhkin A. K. in 2014-2018 from the islands of Kunashir, Iturup, Paramushir, and Shikotan. As a result of the study, the new list of species of the genus Rinodina for the Kuril Islands consists of 17 taxa. One species, Rinodina herrei H. Magn., is new to northeastern Asia and Russia, 14 taxa are new to the Kuril Islands. The genus Rinodina is represented by species with disjunctive distribution by $35.3 \%$ (6 species). They are divided into two groups: East Asian - West American ( $R$. herrei, R. megistospora) and East Asian - East North American (R. ascociscana, R. subminuta, R. tenuis and R. willeyi). East Asian species account for $17.6 \%$ (3 species: R. hypobadia, R. subalbida and R. xanthophaea) of the known number of Rinodina species of the Kuril Islands.

\section{Род Rinodina на Курильских островах (Дальний Восток России)}

\author{
И. А. Галанина ${ }^{1}$ А. К. Ежкин² \\ l Федеральный научный цеентр биоразнообразия наземной биоты Восточной Азии ДВО РАН, \\ пр-т 100-летия Владивостока, 159, г. Владивосток, 690022, Россия \\ ${ }^{2}$ Институт морской геологии и геофизики ДВО РАН, ул. Науки, 1Б, г. Южно-Сахалинск, 693022, Россия
}

\begin{abstract}
Ключевые слова: биоразнообразие, дизъюнктивное распространение, лишайники, новые виды, СевероВосточная Азия, Physciaceae.

Аннотация. Представленная работа основана на исследовании обширного материала, собранного А. К. Ежкиным в 2014-2018 гг. на Курильских островах: Кунашир, Итуруп, Парамушир и Шикотан. В результате исследования новый список видов рода Rinodina для Курильских островов состоит из 17 таксонов. Один вид, Rinodina herrei Н. Magn., является новым для Северо-Восточной Азии и России, 14 таксонов являются новыми для Курильских островов. Род Rinodina на 35,3 \% (6 видов) представлен здесь видами с дизьюнктивным распространением. Они делятся на две группы: восточноазиатско-западно-североамериканские ( $R$. herrei, $R$. megistospora) и восточноазиатско-восточно-североамериканские ( $R$. ascociscana, $R$. subminuta, $R$. tenuis и $R$. willeyi). Виды, ограниченные Восточной Азией, составляют 17,6 \% (3 вида: R. hypobadia, $R$. subalbida и R. xanthophaea) от известного числа видов Rinodina Курильских островов.
\end{abstract}




\section{Introduction}

As well known, the south of the Russian Far East possesses a large flora of vascular plants and cryptogamic organisms (Kharkevich, 1985; Bulakh et al., 1990; Kozhevnikov, Probatova, 2006; Bogacheva et al., 2018). The genus Rinodina (Ach.) Gray remains unexplored in certain territories of Russia or the data about it is often erroneous. Species of Rinodina are relatively difficult to determine because of the wide variety of types of spores, which are distinguished by their development all stages.

The Russian Far East is one of the territories where the genus Rinodina remained poorly studied. Recently, a monograph of the genus Rinodina was published for North America and north of Mexico (Sheard, 2010). This work facilitated an updating of our understanding of the genus in Northeast Asia (Sheard et al., 2017). This revision included parts of Russia and China, Korea and Japan. Many Rinodina species not previously recognized in the Russian Far East, were discovered. These include some species previously thought to be North American endemics. Close links were found with the Rinodina biota of both eastern and western North America (Sheard et al., 2017; Yakovchenko et al., 2018).

The Kuril Islands are located in the northeastern part of the Pacific Ocean, between Hokkaido (Japan) and the Kamchatka Peninsula (Russia). The climate is temperate, monsoon type with cold winters, but milder than in the mainland part with a cool rainy summers. The southern Kuril Islands (Kunashir, Iturup, Shikotan) are the part of the SakhalinHokkaido province of the East Asian floristic region (Takhtajan, 1978). The flora of northern Kuriles (Paramushir) is enriched with arcticalpine elements including American flora representatives (Barkalov, 2002). The flora of South Kuriles is considered a part of the boreal zone with coniferous and mixed coniferous-deciduous forests but also includes tropical and subtropical elements.

The first lichenological investigations on Kuriles were performed by Japanese specialists in the beginning of the twentieth century. The first list of lichens numbered only 44 species Kuriles (Sato, 1936). In 2002 the list of lichens included 260 species for Kuriles (Tchabanenko, 2002), so these list additions of new records are found in several publications (Insarov, Pchelkin, 1984; Tchabanenko, 1999, 2004; Joneson et al., 2004; Makryi et al., 2010; Ezhkin, 2016; Ezhkin, Kordyukov, 2016).

The genus Rinodina in the lichen biota of the Kuril Islands remained unexplored due to its difficult taxonomy. For the Kuril Islands (Kunashir Island), six species of the genus Rinodina were cited (Bredkina et al., 1992; Tchabanenko, 1999; Galanina et al., 2018). These were Rinodina archaea (Ach.) Arnold, R. gennarii Bagl., R. megistospora Sheard et H. Mayrhofer, R. pyrina (Ach.) Arnold, R. sophodes (Ach.) A. Massal., R. xanthophaea Nyl. In our last study (Sheard et al., 2017), it was shown that these species, with the exception of $R$. gennarii, $R$. megistospora, and $R$. xanthophaea, were not found in the Russian Far East. We believe that these species are erroneously listed for the islands. Rinodina gennarii was not found by us, but there is a probability of it being present on coastal rock habitats.

The presented work is based on the study of extensive material collected from different islands (Kunashir, Iturup, Paramushir, and Shikotan). As a result, the list of species for the genus Rinodina in the Kuril Islands includes 17 taxa. One of them is the western North American species - Rinodina herrei $\mathrm{H}$. Magn. - recorded for the first time from Northeast Asia and Russia, and there are additional 14 new records for the Kuril Islands.

\section{Material and methods}

Herbarium specimens collected by the second author (A. K. Ezhkin) during 2014-2018 from the Kuril Islands compose the core material for this study. Voucher specimens are deposited in the herbaria SAK and VLA. Morphological and anatomical characters were analyzed by applying standard light microscopical methods. Full label data of examined specimens are provided for every species. The map (Fig. 1) shows the studied area. A few recent publications have been used to identify samples (Sheard, 2010, 2018; Sheard et al., 2017).

\section{A new species for northeast Asia and Russia}

\section{Rinodina herrei H. Magn. (Fig. 2)}

Specimens examined: "Iturup Island, Baranskogo Volcano surroundings, Kipyashya river valley, oak wood, on bark of Quersus crispula, $225 \mathrm{~m}$. $45^{\circ} 4^{\prime} 43.31^{\prime \prime} \mathrm{N}, 147^{\circ} 59^{\prime} 6.968^{\prime \prime} \mathrm{E} .19$ VIII 2012. A. K. Ezhkin. № 525" (VLA).

The species grows on bark, often heavily dusty, less often on wood and soil. One of the most common species found in southern California, most commonly on Quercus bark (Sheard, 2010).

Previously cited only for North America as an endemic species belonging to the Californian 
floristic element. Distributed in the coastal zone of California, Baja California, and British Columbia (Sheard, 2010). The species is first recorded here for Russia and Northeast Asia, on the bark of Quercus crispula Blume in an oak grove on the Iturup Island. This is another species belonging to the group of East Asian-Western North American species.

The following is a brief description of the species based on the studied samples. Thallus grayish to brown, thin to thick, areolate; areoles to $0.6-1.0$ $\mathrm{mm}$ wide, with margins raised; surface plane, matt; prothallus lacking; sometimes blastidia may proliferate from areole margins. Apothecia erumpent, broadly attached, frequent, to $1-1.5 \mathrm{~mm}$ diameter; disc dark brown to black, quickly becoming convex; thalline margin concolourous with thallus, entire, becoming excluded. Spores to eight per ascus, Type A development, Teichophila-type (16.0-)18-22 $\times$ $8.5-11 \mu \mathrm{m}$. Spot tests all negative. This anatomical and morphological description closely matches the description of the species made by Sheard (2010).

\section{New species for Kuril Islands}

Rinodina ascociscana (Tuck.) Tuck.

Specimens examined: Russia, "Kunashir Island, Dubovoye village surroundings, oak forest, on bark of Quersus crispula Blume, $58 \mathrm{~m}$. $43^{\circ} 46^{\prime} 28.7112^{\prime \prime} \mathrm{N}, 145^{\circ} 31^{\prime} 00.9515^{\prime \prime} \mathrm{E} .23$ VIII 2017. A. K. Ezhkin. № 1462" (SAK); ibid, "Mendeleev volcano, northwestern slope, dark coniferous forest, on bark of Picea jezoensis (Sieb. et Juss.) Carr., 592

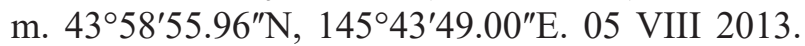
A. K. Ezhkin. № 1454” (VLA); "Iturup Island, Mt. Pereval'naya surroundings, oak forest with Larix, on bark of Quersus crispula, 253 m. $45^{\circ} 07^{\prime} 49.7^{\prime \prime} \mathrm{N}$, $147^{\circ} 47^{\prime} 06.4^{\prime \prime}$ E. 01 VI 2018. A. K. Ezhkin. № 1684, $1685,1692,1693,1695 "$ (VLA).

This species grows on the bark of coniferous and deciduous trees, it is found in mixed deciduous forests in Honshu in Japan, at an altitude of 380-1480 $\mathrm{m}$, on Jeju Island in Korea, at an altitude of 750 $1600 \mathrm{~m}$, and in Gangwon Province, 380-1660 m,

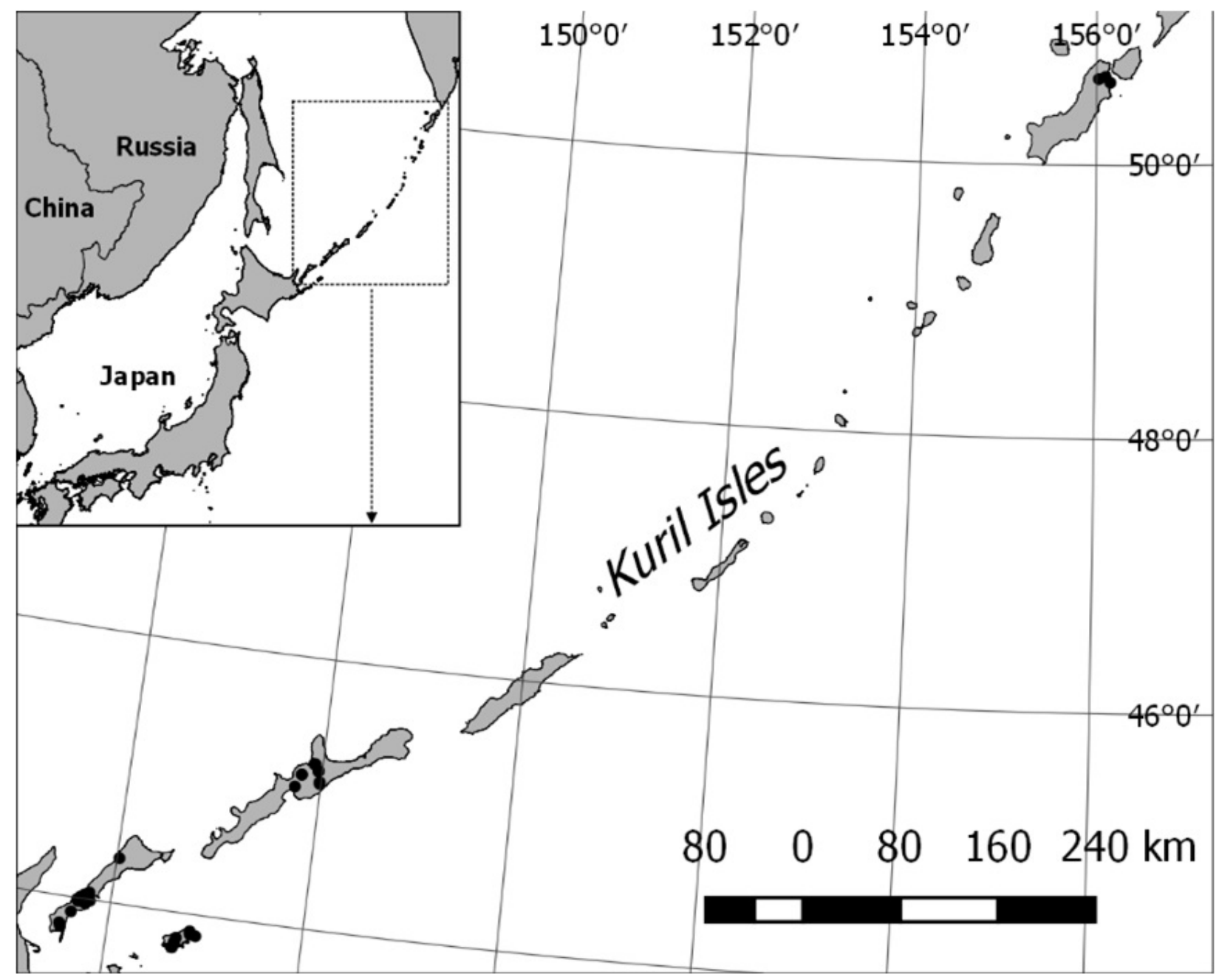

Fig. 1. The places of research of the genus Rinodina in the Kuril Islands of the Russian Far East. 


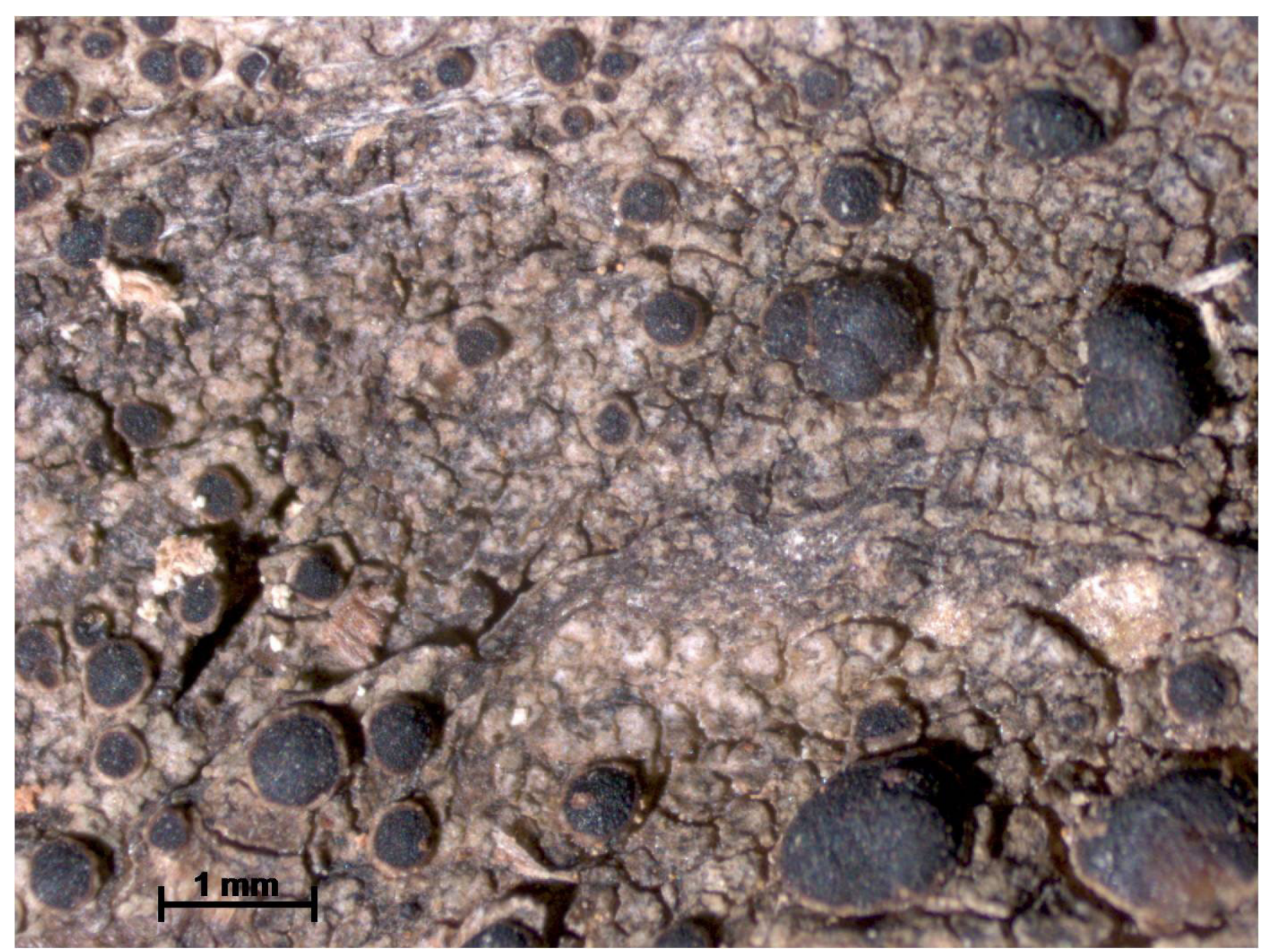

Fig. 2. Rinodina herrei H. Magn.

and Primorye Territory - at low altitudes (Sheard et al., 2017). Rinodina ascociscana was previously considered an endemic species of eastern North America (Sheard, 2010; Lendemer et al., 2014). New for the Kuril Islands.

Rinodina colobinoides (Nyl.) Müll. Arg.

Specimens examined: Russia, "Kunashir Island, Mendeleev volcano surroundings, Lesnaya river valley, mixed forest, on bark of Hydrangea paniculata Sieb., $135 \mathrm{~m} .44^{\circ} 00^{\prime} 04.8^{\prime \prime} \mathrm{N}, 145^{\circ} 42^{\prime} 26.9^{\prime \prime} \mathrm{E} .26 \mathrm{VII}$ 2013. A. K. Ezhkin. № 1453" (VLA).

The species grows on various deciduous trees in North America (Magnolia, Prosopsis, Prunus, Quercus, Sorbus) and is found on the coastal plain around the Gulf of Mexico, and in the Great Smoky Mountains National Park (Sheard, 2010). It is found in tropics of South America, on the Caribbean Islands, the coast of Portugal, in India (Giralt et al., 1995; Giralt, 2001, 2010), in England (Smith et al., 2009). In the latest studies of the genus Rinodina in Northeast Asia (Sheard et al., 2017), the species Rinodina colobinoides was not recorded. It was noted that the species is listed for the south of the Russian Far East by Urbanavichus and Andreev (2010), and based on an earlier reference (Insarov, Pchelkin, 1984; Tchabanenko, 2002) to R. sorediata H. Magn. (as a synonym) on the bark of Quercus mongolica in the Sikhote Alin Mountains (Insarov, Pchelkin, 1984). New for the Kuril Islands.

\section{Rinodina excrescens Vain.}

Specimens examined: Russia, "Shikotan Island, Mt. Shikotan surroundings, mixed forest, bark

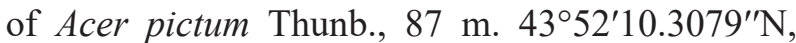
$146^{\circ} 50^{\prime} 40.6319^{\prime \prime}$ E. 20 VI 2017. A. K. Ezhkin. № 1478 " (VLA).

The species was described from West Siberia by Vainio (1928) and is known from very few localities in Europe where it is scattered and very rare (Giralt et al., 1994; Spribille et al., 2006; Galanina et al., 2011). The species grows in Northern America on the bark of living and dead tree trunks (Betula, Abies, Picea, Larix, Thuja) (Sheard, 1995, 2010). Rinodina excrescens was found to be a new record for Japan where it occurs at elevations up to 720 
$1030 \mathrm{~m}$ in Hokkaido (Sheard et al., 2017). It grows on bark of deciduous and coniferous trees (Betula, Alnus, Quercus, Larix, Pinus, Picea, Salix) in Altai Mts., in Dauria (Sokhondinskiy reserve) and in the Far East of Russia (Galanina et al., 2011; Davydov, Printzen, 2012). New for the Kuril Islands.

\section{Rinodina freyi $\mathrm{H}$. Magn.}

Specimens examined: Russia, "Kunashir Island, Lagunnoye lake surroundings, mixed coniferousbroad leaved forest, on bark of Acer pictum, $79 \mathrm{~m}$. $44^{\circ} 2^{\prime} 50.20^{\prime \prime} \mathrm{N}, 145^{\circ} 46^{\prime} 1.613^{\prime \prime}$ E. 17 VIII 2013. A. K. Ezhkin. № 1528" (VLA).

The species is most often found on branches of bushes and deciduous trees but also on branches of conifers. In North America, it is found on a large number of tree species: Abies, Acer, Alnus, Betula, Fraxinus, Picea, Pinus, Quercus, Sorbus, Ulmus, and others, mainly in the southern boreal zone (Sheard, 2010).

Distribution of the species in Europe is poorly understood, although it was described from Europe (Switzerland) (Magnusson, 1947), and the species is also given for Germany (Wirth et al., 2013).

Sheard (2010) saw specimens of this species from the Alps and Scandinavia and indicated a confusion with the species $R$. septentrionalis from Europe (Giralt, Mayrhofer, 1995). Rinodina freyi is most common species of the genus in North America, being frequent in both the east and west of the continent (Sheard, 2010). It has also been reported from western Mongolia (Hauck et al., 2013). Recently the species was found in Japan and Russia (Sheard et al., 2017). In Russia the species is reported for the Magadan Region, Kamchatka Peninsula, Sakhalin Island, Khabarovsk and Primorye Territory (Sheard et al., 2017). New for the Kuril Islands.

\section{Rinodina hypobadia Sheard}

Specimens examined: Russia, "Shikotan Island, Mt. Notoro surroundings, elfin woodland, on bark of Alnus hirsuta (Spach.) Rupr., $238 \mathrm{~m}$. $43^{\circ} 46^{\prime} 10.7652^{\prime \prime} \mathrm{N}, 146^{\circ} 41^{\prime} 56.0255^{\prime \prime}$ E. 14 VI 2017. A. K. Ezhkin. № 1487” (VLA).

The species was recently described from Northeast Asia (Sheard et al., 2017). It grows on bark of Abies sachalinensis, Salix sp., Populus sp. in mixed and deciduous forests. Rinodina hypobadia is infrequent in Northeastern Asia, where it has been recorded in Japan and Russia, only from Hokkaido, Primorye Territory and southern Sakhalin Island. New for the Kuril Islands.

\section{Rinodina oleae Bagl.}

Specimens examined: Russia, "Kunashir Island, Lagunnoye lake surroundings, mixed coniferousbroad leaved forest, on bark of Kalopanax septemlobus, $79 \mathrm{~m} .4^{\circ} 2^{\prime} 50.20^{\prime \prime} \mathrm{N}, 145^{\circ} 46^{\prime} 1.613^{\prime \prime} \mathrm{E}$, 17 VIII 2013, A. K. Ezhkin. № 1593” (SAK); "Iturup Island, Kurilsk Airport surroundings, oak forest, on bark of Acer pictum, $48 \mathrm{~m} .45^{\circ} 12^{\prime} 51.54^{\prime \prime} \mathrm{N}$, $147^{\circ} 55^{\prime} 16.02^{\prime \prime}$ E. 05 V 2018. A. K. Ezhkin. № 1710" (VLA).

On bark of deciduous and coniferous trees, often on Sorbus and Acer (Sheard, 2010). On bark of Quercus, Fraxinus in Primorye Territory (Sheard et al., 2017) and on bark of Kalopanax septemlobus on Kunashir Island.

The species is known from Southern Europe (Giralt, 2001) and North America, where it has a scattered distribution (Sheard, 2010). As a synonym for $R$. gennarii Bagl., it is reported for many regions of Russia (Urbanavichus, Andreev, 2010). The close relationship of these species has been discussed in several papers (Giralt, Mayrhofer, 1995; Trinkaus et al., 1999; Giralt, 2001), also using molecular methods in recent works (Helms et al., 2003; Kaschik, 2006). These species are currently treated as separate (Sheard, 2010). Samples on mossy stones in seaside habitats are defined as Rinodina gennarii, while $R$. oleae occurs on bark and has smaller spores (Sheard, 2010). In East Asia, the species is known from China and Japan (Sheard et al., 2017) and was recently recorded from Korea (Kondratyuk et al., 2013). In the Russian Far East, R. olea was first noted in the Khabarovsk Region (Yakovchenko et al., 2013) and then in Primorye Territory (Sheard et al., 2017). New for the Kuril Islands.

Rinodina polyspora $\mathrm{Th}$. Fr.

Specimens examined: Russia, "Iturup Island, Kurilka River valley, mixed streamside forest, on bark of Populus maximowiczii Henry., $29 \mathrm{~m}$. $45^{\circ} 13^{\prime} 07.4^{\prime \prime} \mathrm{N}, 147^{\circ} 54^{\prime} 50.9^{\prime \prime}$ E. 30 VII 2018. A. K. Ezhkin. № 1686" (SAK); "ibid, on bark of Padus ssiori F.Schmidt., 24 m. 45 $13^{\prime} 12.1^{\prime \prime} \mathrm{N}$, $147^{\circ} 54^{\prime} 13.8^{\prime \prime}$ E. 30 V 2018, A. K. Ezhkin. № 1687" (VLA); ibid, "on bark of Populus maximowiczii, 30 m. $45^{\circ} 12^{\prime} 59.8^{\prime \prime} \mathrm{N}, 147^{\circ} 55^{\prime} 05.8^{\prime \prime}$ E. $30 \mathrm{~V}$ 2018. A. K. Ezhkin. № 1688" (VLA); ibid, "Kurilsk town surroundings, mixed forest, on bark of Prunus sp., 24 m. $45^{\circ} 13^{\prime} 12.1^{\prime \prime} \mathrm{N}, 147^{\circ} 54^{\prime} 13.8^{\prime \prime} \mathrm{E} .30 \mathrm{~V} 2018$. A. K. Ezhkin. № 1694” (VLA).

The species grows on smooth bark of deciduous trees (Acer, Alnus, Fagus, Fraxinus, Populus, Quercus, Rhamnus (Mayrhofer, Moberg, 2002; 
Kotlov, 2008; Sheard, 2010). Rinodina polyspora was found in central Europe, rarely in southern and central Sweden and in southern Finland (Mayrhofer, Moberg, 2002), in North America in the Great Lakes region and on the Pacific Coast (Sheard, 2010). Rinodina polyspora has recently been reported from Korea (Joshi et al., 2013) and from Japan (Sheard et al., 2017). In Russia, it is found in Karelia, the Leningrad Region, Tatarstan, Western and Southern Siberia (Tyumen Region, Baikal Region, Sayan Mountains) (Kotlov, 2008). New for the Kuril Islands.

\section{Rinodina roscida (Sommerf.) Arnold}

Specimens examined: Russia, "Paramushir Island, coast, on mossy soil, 57 m. $50^{\circ} 36^{\prime} 15.6708^{\prime \prime} \mathrm{N}$, $156^{\circ} 09^{\prime 2} 27.7236^{\prime \prime}$ E. 03 X 2017. A. K. Ezhkin. № $1455^{\prime \prime}$ (VLA).

The species grows on mosses and plant debris, less often on wood, soil or animal horns, on calcareous substrates (soil) in arctic and highland areas (Mayrhofer, Moberg, 2002; Kotlov, 2008), more rarely on the litter of arctic hare and partridge (Sheard, 2010).

The species is found in central Europe (Wirth et al., 2013), sparsely and rarely in Scandinavia, rarely in southern Europe (Mayrhofer, Moberg, 2002). In North America, it is common in the Arctic, especially in the west, and southwards in the Rocky Mountains (Sheard, 2010). In Russia, it is widely distributed in the northern and mountainous regions: in the Arctic (Franz Josef Land, Novaya Zemlya, Taimyr, Severnaya Zemlya, Yakutia, Chukotka), Murmansk Region, Karelia, Leningrad Region, Arkhangelsk Region, Republic of Komi, Western Siberia (Krasnoyarsk Territory), South Siberia (Transbaikalia, Sayan Mountains), in Asia (Caucasus, Himalayas, Mongolia, China) (Makarova, Katenin, 1983; Kotlov, 2008). New for the Kuril Islands.

\section{Rinodina subalbida (Nyl.) Vain.}

Specimens examined: Russia, "Kunashir Island, Rurui Volcano surroundings, Prosolovslie springs, old grows mixed coniferous-broad leaved forest, on bark of Sorbus commixta Hedl., 15 m. $44^{\circ} 19^{\prime} 58.43^{\prime \prime} \mathrm{N}, 146^{\circ} 1^{\prime} 14.52^{\prime \prime}$ E. 19 VI 2014. A. K. Ezhkin. 1555" (SAK); ibid, "Tretyakova village surroundings, old grows mixed coniferousbroad leaved forest, on bark of Bothrocaryum controversum (Hemsl. Ex Prain) Poyarkova, 163 m. $43^{\circ} 58^{\prime} 28.38^{\prime \prime} \mathrm{N}, 145^{\circ} 39^{\prime} 49.28^{\prime \prime} \mathrm{E}, 22$ VI 2015. A. K. Ezhkin. № 1561” (VLA); ibid, "Belkina river valley, dark conifer forest, on bark of Picea

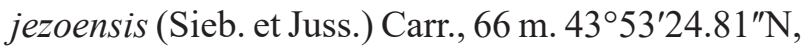
$145^{\circ} 36^{\prime 2} 28.30^{\prime \prime E} .23$ VI 2014. A. K. Ezhkin. № 1574" (VLA); "Baranskogo Volcano surroundings, near the Kipyashaya river, oak wood, on bark of Quersus crispula, $225 \mathrm{~m} .45^{\circ} 4^{\prime} 43.31^{\prime \prime} \mathrm{N}, 147^{\circ} 59^{\prime} 6.968^{\prime \prime} \mathrm{E} .21$ VIII 2015. A. K. Ezhkin. № 522, 521, 523, 1576" (VLA); ibid, "Lagunnoye lake surroundings, mixed coniferous-broad leaved forest, on bark of Picea jezoensis, 65 m. $44^{\circ} 2^{\prime} 49.70^{\prime \prime} \mathrm{N}, 145^{\circ} 45^{\prime} 59.09^{\prime \prime} \mathrm{E} .17$ VIII 2013. A. K. Ezhkin. № 1521” (VLA); ibid, “on bark of Taxus cuspidate Siebold et Zucc. ex Endl., $44^{\circ} 2^{\prime} 50.20^{\prime \prime} \mathrm{N}, 145^{\circ} 46^{\prime} 1.613^{\prime \prime}$ E. 17 VIII 2013. A. K. Ezhkin. № 1522" (VLA); ibid, "on bark of Picea jezoensis, 79 m. $44^{\circ} 2^{\prime} 50.20^{\prime \prime} \mathrm{N}, 145^{\circ} 46^{\prime} 1.613^{\prime \prime} \mathrm{E}$. 17 VIII 2013. A. K. Ezhkin. № 1526, 1534, 1537" (VLA); ibid, "on bark of Acer pictum, $65 \mathrm{~m}$. $44^{\circ} 2^{\prime} 49.70^{\prime \prime} \mathrm{N}, 145^{\circ} 45^{\prime} 59.09^{\prime \prime}$ E. 17 VIII 2013. A. K. Ezhkin. № 1529” (VLA); ibid, "Mendeleev volcano, northwestern slope, dark coniferous forest with Betula ermanii Cham., on bark of Picea jezoensis, 592 m. 43 $58^{\prime} 55.96^{\prime \prime} \mathrm{N}, 145^{\circ} 43^{\prime} 49.00^{\prime \prime} \mathrm{E}$. 05 VIII 2013. A. K. Ezhkin. № 1524” (VLA); “Iturup Island, Kurilsk Airport surroundings, oak forest, on bark of Quersus crispula, 93 m. $45^{\circ} 12^{\prime} 25.72^{\prime \prime} \mathrm{N}$, $147^{\circ} 54^{\prime} 30.54^{\prime \prime}$ E. 03 VIII 2018. A. K Ezhkin. № 1701, 1703" (VLA); ibid, "on bark of Quersus crispula, $101 \mathrm{~m} .4^{\circ} 16^{\prime} 11.15^{\prime \prime} \mathrm{N}, 147^{\circ} 58^{\prime} 44.36^{\prime \prime} \mathrm{E}$. 04 VIII 2018. A. K. Ezhkin. № 1704, 1705, 1706" (VLA); ibid, "Kurilka river valley, Kurilsk town surroundings, oak forest, on bark of Quersus crispula, $101 \mathrm{~m} .45^{\circ} 15^{\prime} 53.89^{\prime \prime} \mathrm{N}, 147^{\circ} 56^{\prime} 13.94^{\prime \prime} \mathrm{E} .29$ VII 2018. A. K. Ezhkin. № 1715” (VLA); ibid, “Mt. Pereval'naya surroundings, oak forest with abies, on

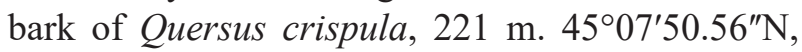
$147^{\circ} 47^{\prime 2} 21.93$ "E. 01 VI 2018. A. K Ezhkin. № 1709" (VLA).

The species is found on bark of coniferous and deciduous trees (Abies, Alnus, Berberis, Fagus, Malus, Picea, Prunus, Quercus, Salix, Sorbus), often in mixed and deciduous forests (Sheard et al., 2017). A complete description of the species was first given recently (Sheard et al., 2017).

Rinodina subalbida was described from Japan and was recently found in South Korea and the southern part of far eastern Russia (Sheard et al., 2017). This is an East Asian species, new for the Kuril Islands.

Rinodina subminuta $\mathrm{H}$. Magn.

Specimens examined: Russia, "Kunashir Island, Mendeleev Volcano, birch forest with Betula ermanii, on bark of Acer ukurunduense Trautv. \& 
C.A. Mey, 627 m. $43^{\circ} 58^{\prime} 53.47^{\prime \prime} \mathrm{N}, 145^{\circ} 43^{\prime} 51.48^{\prime \prime} \mathrm{E}$ 05 VIII 2013. A. K. Ezhkin. № 1531” (VLA); ibid, "Aliger lake surroundings, mixed coniferous-broad leaved forest, on bark of Quersus crispula, $627 \mathrm{~m}$. $44^{\circ} 01^{\prime} 45.8328^{\prime \prime} \mathrm{N}, 145^{\circ} 43^{\prime} 12.6732^{\prime \prime}$ E. 20 VI 2014. A. K. Ezhkin. № 1533" (VLA); ibid, "Zmeyinyi creek valley, mixed coniferous-broad leaved forest, on bark of Acer pictum, 38 m. $44^{\circ} 0^{\prime} 27.66^{\prime \prime} \mathrm{N}$, $145^{\circ} 40^{\prime} 57.30^{\prime \prime}$ E. 31 VII 2013. A. K. Ezhkin. № 1538, 1539" (SAK); ibid, "Tretyakova village surroundings, old grows mixed coniferous-broad leaved forest, bark of Kalopanax septemlobus, 163

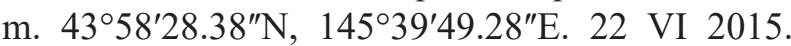
A. K. Ezhkin. № 1572” (VLA).

The species is found on the bark of coniferous and deciduous trees (Abies, Alnus, Berberis, Fagus, Hydrangea, Malus, Picea, Quercus, Salix, Sorbus) (Sheard et al., 2017), in Russia often in mixed and deciduous forests. It has a wide range of distribution (Sheard et al., 2017). The species is known from eastern Asia with a distribution spanning Russia, Japan and the Korean Peninsula (Sheard et al., 2017). It is a widespread species in the south of the Far East of Russia and in the east of the North America (Great Lakes Region, Appalachian Mountains) (Sheard, 2010). The distribution of Rinodina subminuta is similar to that of $R$. ascociscana, $R$. excrescens and $R$. subparieta (Galanina et al., 2011; Sheard et al., 2017). This is an exclusively East Asian-Eastern North American species, new for the Kuril Islands.

Rinodina subparieta (Nyl.) Zahlbr.

Specimens examined: Russia, "Kunashir Island, Dubovoye village surroundings, oak forest, on bark

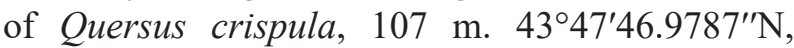
$145^{\circ} 30^{\prime} 15.2819^{\prime \prime}$ E. 23 VIII 2017. A. K. Ezhkin. № 1460 " (VLA).

The species is found on the bark of coniferous and broad-leaved trees (Abies, Alnus, Betula, Castanea, Chosenia, Picea, Prunus, Quercus, Salix, Taxus), in Russia it is found in deciduous and mixed forests, and same along river valleys. It occurs from the sea level to $2550 \mathrm{~m}$ (Sheard et al., 2017). It is known from Scotland (Giavarini et al., 2009), Scandinavia and Austria (Tonsberg, 1992; Mayrhofer, Moberg, 2002), from the Khentey region of Mongolia (Hauck, Javkhlan, 2006) and from eastern and western North America (Sheard, 2010; Spribille et al., 2010). The species was previously reported from eastern Asia with a distribution spanning Russia, Japan and Korea (Sheard et al., 2017). It is a widespread species in Russia from the Caucasus to the Far East (Urbanavichus, Andreev, 2010;
Himelbrant, Stepanchikova, 2011; Galanina, 2013). New for the Kuril Islands.

Rinodina tenuis Müll. Arg.

Specimens examined: Russia, "Kunashir Island, Belkina river valley, mixed coniferous-broad leaved forest, on bark of Picea jezoensis, $66 \mathrm{~m}$. $43^{\circ} 53^{\prime} 24.81^{\prime \prime} \mathrm{N}, 145^{\circ} 36^{\prime} 28.30^{\prime \prime}$ E. 23 VI 2014. A. K. Ezhkin. № 516" (SAK); ibid, "Lagunnoye village surroundings, mixed coniferous-broad leaved forest, on bark of Ulmus laciniata Trantv., $65 \mathrm{~m}$. $44^{\circ} 2^{\prime} 49.70^{\prime \prime} \mathrm{N}, 145^{\circ} 45^{\prime} 59.09^{\prime \prime} \mathrm{E} .17$ VIII 2013. A. K. Ezhkin. № 1523" (VLA); ibid, "on bark of Picea jezoensis, A. K. Ezhkin. № 1527, 1535, 1536”(VLA); ibid, "Dubovoye village surroundings, oak forest, on bark of Quersus crispula, 107 m. 43 47'46.9787"N, $145^{\circ} 30^{\prime} 15.2819^{\prime \prime}$ E. 23 VIII 2017. A. K. Ezhkin. № 1470" (VLA); ibid, "13 km from the YuzhnoKurilsk town, Mendeleev Volcano surroundings, mixed forest, on bark of Padus ssiorii, $134 \mathrm{~m}$. $44^{\circ} 01^{\prime} 13.9403^{\prime \prime} \mathrm{N}, 145^{\circ} 43^{\prime} 40.2780^{\prime \prime}$ E. 27 VIII 2017. A. K. Ezhkin. № 1472" (VLA); "Shikotan Island, Mt. Notoro surroundings, elfin woodland, on bark of old Betula ermanii, 238 m. 43 $46^{\circ} 10.7652^{\prime \prime} \mathrm{N}$, $146^{\circ} 41^{\prime} 56.0255^{\prime \prime}$ E. 14 VI 2017. A. K. Ezhkin. № 1469” (VLA); ibid, "Tserkovnaya Bay, dark coniferous forest, on bark of Picea jezoensis, 39 m. $43^{\circ} 44^{\prime} 13.9451^{\prime \prime} \mathrm{N}, 146^{\circ} 41^{\prime} 12.8760^{\prime \prime} \mathrm{E} .12$ VI 2017. A. K. Ezhkin. № 1484" (VLA); ibid, "mixed forest, on bark of Salix udensis Trautv., 47 m. 434ㄴ $16.4904^{\prime \prime} \mathrm{N}, 146^{\circ} 40^{\prime} 57.9216^{\prime \prime} \mathrm{E} .15$ VI 2017. A. K. Ezhkin. № 1485" (VLA); ibid, “on

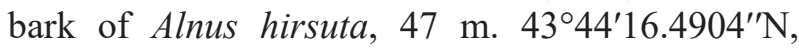
$146^{\circ} 40^{\prime} 57.9216^{\prime \prime}$ E. 15 VI 2017. A. K. Ezhkin. № $1487^{\prime \prime}$ (VLA).

The species is found on the bark and branches of coniferous trees (Abies, Picea) as well as on mossy horizontal logs (Sheard et al., 2017). In the Kuril Islands it is found in mixed forests on coniferous and broad-leaved species (Alnus, Betula, Padus, Picea Quercus, Salix, Ulmus). The species formerly known from Great Lakes-Appalachian region in North America (Sheard, 2010) and in Japan (Kurokawa, Kashiwadani, 2006). Although widespread in eastern North America, it is relatively infrequent (Sheard, 2010; Lendemer et al., 2014, as $R$. adirondackii $\mathrm{H}$. Magn.). Most recently, Rinodina tenuis was found in Russia, where the species seems to have a narrow distribution in the boreal zone of Khabarovsk Region, Sakhalin Island, and has a couple records from Hokkaido (Japan) (Sheard et al., 2017). We found this species is quite frequent on the southern Kuril Islands (Kunashir and Shikotan), 
the closest to Japan. This is an exclusively East Asian-Eastern North American species, new for the Kuril Islands.

\section{Rinodina willeyi Sheard et Giralt}

Specimens examined: Russia, "Kunashir Island, Lagunnoye village suburbs, mixed coniferousbroad leaved forest, on bark of Phellodendron sakhalinense (F. Schmidt) Sarg., 79 m. $44^{\circ} 02^{\prime} 50.2^{\prime \prime} \mathrm{N}$, $145^{\circ} 46^{\prime} 01.6^{\prime \prime}$ E. 01 VIII 2015. A. K. Ezhkin. № 1463" (SAK); "Shikotan Island, Mt. Notoro surroundings, elfin woodland, on bark of old Betula ermanii, $238 \mathrm{~m}$. 434ㅇ' $10.7652^{\prime \prime} \mathrm{N}, 146^{\circ} 41^{\prime} 56.0255^{\prime \prime} \mathrm{E} .14$ VI 2017. A. K. Ezhkin. № 1469” (VLA); ibid, "riparian forest, on bark of Padus ssiorii, 92 m. 43 46 $46^{\prime} 40.9296^{\prime \prime N}$, $146^{\circ} 42^{\prime} 08.0495^{\prime \prime}$ E. 17 VI 2017. A. K. Ezhkin. № 1471" (SAK); ibid, "Mt. Brysova surroundings, mixed forest, on bark of Acer pictum, $56 \mathrm{~m}$. $43^{\circ} 50^{\prime} 54.6^{\prime \prime} \mathrm{N}, 146^{\circ} 51^{\prime} 03.8^{\prime \prime} \mathrm{E} .19$ VI 2017. A. K. Ezhkin. № 1482” (VLA).

The species was found on the bark and branches of coniferous trees (Abies, Picea) as well as on mossy horizontal logs (Sheard et al., 2017) and in the Kuril Islands it is found in mixed forests on coniferous and broad-leaved species (Alnus, Betula, Padus, Picea, Quercus, Salix, Ulmus).

This species was described from North America (Sheard, 1995), and before our research in northeastern Asia (Sheard et al., 2017) was known only from North America. The species was noted in Japan (Hokkaido and Honshu islands) and Russia (Kamchatka peninsula) (Sheard et al., 2017). Now the species is found in the southern Kurils for the first time (Kunashir, Shikotan), close to Japan. This record is another addition to the list of Eastern AsiaEastern North American disjunct species.

\section{Species previously noted for the Kuril Islands}

\section{Rinodina gennari Bagl.}

The species is known from southern Europe mainly on a stony substrate (Giralt, 2001) and from North America frequent on maritime rocks. Not recorded outside coastal regions in North America (Sheard, 2010). Recently Rinodina gennari was found in coastal Japan on mortar and on vertical rock $100 \mathrm{~m}$ from the seashore (Sheard et al., 2017). Rinodina gennari has been reported for many regions of Russia as a synonym for the species $R$. oleae Bagl. (Urbanavichus, Andreev, 2010). These species are treated as separate taxon by Sheard (2010). See $R$. oleae below for more details. Rinodina gennari is reported for the Kuril Islands (Kunashir Island)
(Bredkina et al., 1992; Chabanenko, 1999), but we did not find the species on the Kuril Islands although it may well be present.

Rinodina megistospora Sheard et H. Mayrhofer Specimens examined: Russia, "Iturup Island, Baranskogo Volcano surroundings, Kipyashya river valley, oak wood, on bark of Quersus crispula, 225 m. $45^{\circ} 4^{\prime} 43.31^{\prime \prime} \mathrm{N}, 147^{\circ} 59^{\prime} 6.968^{\prime \prime}$ E. 21 VIII 2015. A. K. Ezhkin. № 563" (SAK); ibid, "Kurilka river valley, oak wood with Kalopanax septemlobus (Thunb. ex. A. Murray) Koidz., on bark of Quercus crispula, $225 \mathrm{~m} .4^{\circ} 07^{\prime} 49.84^{\prime \prime} \mathrm{N}, 147^{\circ} 47^{\prime} 21.44^{\prime \prime} \mathrm{E}$. 25 VIII 2012. A. K. Ezhkin. № 520" (VLA); ibid, "Mt. Pereval'naya surroundings, Iturup Island, oak forest with Larix, on bark of Quersus crispula, 253 m. $45^{\circ} 07^{\prime} 49.7^{\prime \prime} \mathrm{N}, 147^{\circ} 47^{\prime} 06.4^{\prime \prime} \mathrm{E}, 01$ VI 2018. A. K. Ezhkin. № 1678” (VLA); "ibid, Kurilka river valley, oak forest with birch, on bark of Quersus crispula, 243 m. 45 $10^{\prime} 15.6^{\prime \prime} \mathrm{N}, 147^{\circ} 57^{\prime} 27.8^{\prime \prime}$ E. 28 VIII 2018. A. K. Ezhkin. № 1679, 1681, 1682" (VLA); ibid, "oak wood, on bark of Quersus crispula, $246 \mathrm{~m}$. $45^{\circ} 10^{\prime} 12.2^{\prime \prime} \mathrm{N}, 147^{\circ} 57^{\prime} 21.6^{\prime \prime} \mathrm{E}, 28$ V 2018. A. K. Ezhkin. № 1680" (VLA).

The species grows on bark of Quercus crispula. First described from a Quercus stand at the type locality in southern Oregon, in a relatively high rainfall region close to the coast (Sheard et al., 2011). Recent studies of the genus Rinodina in northeast Asia suggesting that Rinodina megistospora may be widespread but infrequent on the mainland (Sheard et al., 2017). Now the species is recorded also from near coastal localities at low elevations in Hokkaido, Japan and from 1610-1630 m in Kochi Prov., Shikoku Island. The species also occurs in the Sikhote Alin' Mountains, Primorye Territory, and in the Khomi Mountains, Khabarovsk Region (Sheard et al., 2017) and in the Sakhalin Region (Sakhalin and Iturup islands) (Galanina et al., 2018). The species belongs to the Eastern Asiatic-Western North American group of disjunct species.

\section{Rinodina xanthophaea (Nyl.) Zahlbr.}

Specimens examined: Russia, "Kunashir Island, Tretyakova village surroundings, old grows mixed coniferous-broad leaved forest, bark of Phellodendron sakhalinense, $163 \mathrm{~m} .43^{\circ} 58^{\prime} 28.38^{\prime \prime} \mathrm{N}$, $145^{\circ} 39^{\prime} 49.28^{\prime \prime}$ E. 22 VI 2015. A. K. Ezhkin. № 542" (SAK); ibid, "Mt. Mechnikov, Mendeleev volcano surroundings, dark coniferous forest with Picea glehnii (Fr. Schmidt) Mast.), on bark of

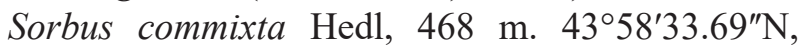
$145^{\circ} 43^{\prime} 19.81^{\prime \prime}$ E. 06 VIII 2013. A. K. Ezhkin. № 
1452" (VLA); ibid, "13 km from the YuzhnoKurilsk town, Mendeleev Volcano surroundings, mixed forest, bark of Padus ssiorii, $134 \mathrm{~m}$. $44^{\circ} 01^{\prime} 13.9403^{\prime \prime} \mathrm{N}, \quad 145^{\circ} 43^{\prime} 40.2780^{\prime \prime} \mathrm{E} .27$ VIII 2017. A. K. Ezhkin. № 1472" (VLA); "Shikotan Island, Mt. Notoro surroundings, mixed forest, on bark of Acer pictum, 50 m. $43^{\circ} 46^{\prime \prime} 50.6603^{\prime \prime} \mathrm{N}$, $146^{\circ} 42^{\prime} 16.3872^{\prime \prime}$ E. 17 VI 2017. A. K. Ezhkin. № 1475, 1465" (VLA); "Shikotan Island, Gorobets river valley, mixed forest, on bark of Acer pictum, 69 m. $43^{\circ} 48^{\prime} 41.2776^{\prime \prime} \mathrm{N}, 146^{\circ} 42^{\prime} 52.2395^{\prime \prime} \mathrm{E} .16$ VI 2017. A. K. Ezhkin. № 1476" (VLA); ibid, "Tserkovnaya Bay, mixed forest, on bark of Abies sakhalinensis F. Schmidt., 47 m. 43ํ4'16.4904"N $146^{\circ} 40^{\prime} 57.9216^{\prime \prime}$ E. 15 VI 2017. A. K. Ezhkin. № 1481" (VLA); "Iturup Island, Baranskogo Volcano surroundings, near the Kipyashaya river, oak wood, on bark of Quersus crispula, $225 \mathrm{~m} .4^{\circ} 4^{\prime} 43.31^{\prime \prime} \mathrm{N}$, $147^{\circ} 59^{\prime} 6.968^{\prime \prime}$ E. 21 VIII 2015. A. K. Ezhkin. № 1497, 1576 " (VLA).

The species was found on the bark of coniferous and broad-leaved trees (Abies, Alnus, Betula, Castanea, Fagus, Picea, Quercus, Salix, Sorbus) (Sheard et al., 2017). Elsewhere in Russia it is found in deciduous and mixed forests. It has a wide altitudinal range in Northeast Asia, it occurs from sea level to $1700 \mathrm{~m}$ (Sheard et al., 2017).

The species was described from Japan (Nylander, 1890) and has been previously recorded from Russia (Oxner, 1948; Pczelkin, 1987; Tchabanenko, 2002; Galanina, 2008; Skirina, 2010, 2012; Urbanavichene, Skirina, 2011; Rodnikova, 2012, 2013; Yakovchenko et al., 2013). It is widespread and has been reported as far west as the Khamar-Daban Mountains in the Baikal region (Urbanavichene, 2010), from Gora Olocha in the Stanovoye Nagor'e Mountains in Amurskaya Oblast' (Urbanavichene, Skirina, 2011) and from the Jewish Autonomous
Region (Urbanavichene, Skirina, 2011), also as the host of Ovicuculispora parmeliae (Berk. et Curt.) Etayo (Zhurbenko, 2014). It was recently reported as new to Korea (Kondratyuk et al., 2016). This is East Asian species.

\section{Discussion}

The species composition of the genus Rinodina of the Kuril Islands reflects a variety of biogeographic connections. The genus Rinodina is for $35.3 \%$ (6 species) presented here by species with disjunctive distributions in the south of Far East of Russia and in western or eastern parts of North America. For the most part, these species were considered to be endemic in North America until recently. Species with such distribution are divided into two groups: East Asian-Western North American ( $R$. herrei, R. megistospora) and East Asian-Eastern North American (R. ascociscana, R. subminuta, R. tenuis, and $R$. willeyi). Species limited to East Asia make up $17.6 \%$ (3 species: R. hypobadia, R. subalbida and $R$. xanthophaea) of the known number of Rinodina species of the Kuril Islands. Other species are widespread in both hemispheres (1 species $R$. colobinoides), or the oroarctic region (1 species $R$. roscida), or in the temperate belt of the Holarctic (35.3 \% - 6 species: $R$. excrescens, $R$. freyi, $R$. gennari, $R$. oleae, $R$. polyspora, $R$. subparieta).

\section{Acknowledgment}

We are very grateful for the consultation and assistance in identifying the samples to Dr. J. W. Sheard, a monographer of the Rinodina family in North America.

The work is partly supported by RFBR grants: 18-04-00098, 15-29-02382, 19-54-50010.

\section{REFERENCES}

Barkalov V. Yu. 2002. Flora of the Kuril Islands. Dalnauka, Vladivostok, 468 pp. [In Russian]. (Баркалов В. Ю. Флора Курильских островов. Владивосток: Дальнаука, 2009. 468 с.).

Bredkina L. I., Dobrysh A. N., Makarova I. I., Titov A. N. 1992. To the lichen flora of Kunashir Island (Kuril Islands). Novosti Sist. Nizsh. Rast. [Novit. Syst. Pl. non Vasc.] 28: 90-94 [In Russian]. (Бредкина Л. И., Добрыш A. А., Макарова И. И., Титов А. Н. К флоре лишайников острова Кунашир (Курильские острова) // Новости сист. низш. раст., 1992. Т. 28. С. 90-94).

Bogacheva A. V., Bulakh E. M., Bukharova N. V., Galanina I. A., Egorova L. N., Ezhkin A. K., Petrunenko E. A. 2018. Mycobiota dalnevostochnykh dubnyakov [Mycobiota of the far eastern oak forests]. Dalnauka, Vladivostok, 232 pp. [In Russian]. (Богачева А. В., Булах Е. М., Бухарова Н. В., Галанина И. А., Егорова Л. Н., Ежкин $\boldsymbol{A}$. К., Петруненко $\boldsymbol{E}$. A. Микобиота дальневосточных дубняков. Владивосток: Дальнаука, 2018. 232 с.).

Bulakh E. M., Vasser, S. P., Nazarova M. M., Nezdoyminogo E. L. 1990. Nizshie rasteniya, griboy i mokhoobraznye sovetskogo Dalnego Vostoka [Lower plants, fungi and bryophytes of the Soviet Far East. Mushrooms Basidiomycetes]. 1. Science, Leningrad, 407 pp. [In Russian]. (Булах Е. М., Вассер С. П., Назарова М. М., Нездойминого 
E. Л. Низшие растения, грибы и мохообразные советского Дальнего Востока. Грибы Базидиомицеты. 1. Л.: Наука, 1990. 407 с.).

Davydov E. A., Printzen C. H. 2012. Rare and noteworthy boreal lichens from the Altai Mountains (South Siberia, Russia). The Bryologist. 115(1): 61-73. DOI: 10.1639/0007-2745.115.1.61

Ezhkin A. K. 2016. Lichens of wood substrate in areas of solfataric activity of the Mendeleev volcano on the Kunashir Island. In: Prirodnyye katastrofy: izucheniye, monitoring, prognoz [Nature disasters research, monitoring, forecast. Materials of the 6th Sakhalin Youth Science School]. Yuzhno-Sakhalinsk, 372-374 pp. [In Russian]. (Ежкин $\boldsymbol{A}$. $\boldsymbol{K}$. Лишайники древесных субстратов в местах проявления сольфатарной активности вулкана Менделеева, о. Кунашир // Природные катастрофы: изучение, мониторинг, прогноз: материалы VI Сахалинской молод. науч. школы. Южно-Сахалинск, 2016. С. 372-374).

Ezhkin A. K., Kordyukov A. V. 2016. Features of changes in the parameters of the epiphytic lichen cover in the vicinity of the Mendeleev Volcano (Kunashir Island, southern Kuriles). Vestnik Botanicheskogo sada-instituta [Bulletin of the Botanical Garden-Institute] 15: 23-25 [In Russian]. (Ежкин А. К., Кордюков А. В. Особенности изменения параметров эпифитного лишайникового покрова в окрестностях вулкана Менделеева (остров Кунашир, южные Курилы) // Вестник Ботанического сада-института, 2016. Вып. 15. С. 23-25).

Galanina I. A. 2008. Sinusii epifitnykh lishaynikov v dubovykh lesakh Primorskogo Kraya [Synusiae of epiphytic lichens in oak forests of the south Primorye Region]. Dalnauka, Vladivostok, 238 pp. [In Russian]. (Галанина И. А. Синузии эпифитных лишайников в дубовых лесах Приморского края. Владивосток: Дальнаука, 2008. 238 с.).

Galanina I. A. 2013. Lichens of fir-spruce and larch forests with an undergrowth of Kuril bamboo in the south of Sakhalin Island. Vestnik Severo-Vostochnogo nauchnogo tsentra DVO RAN [Bulletin of the Northeastern Research Center of FEB RAS] 2, 34: 86-94 [In Russian]. (Галанина И. А. Лишайники пихтово-еловых и лиственничных лесов с подлеском курильского бамбука на юге Сахалина // Вестник Северо-Восточного научного центра ДВО РАН, 2013. № 2, вып. 34. С. 86-94).

Galanina I. A., Ezhkin A. K., Yakovchenko L. S. 2018. New records of Rinodina megistospora (Physciaceae, lichenized Ascomycota) from north-eastern Asia. Novosti Sist. Nizsh. Rast. [Novit. Syst. Pl. non Vasc.]. 52(1): 133-139.

Galanina I. A., Yakovchenko L. S., Tsarenko N. A., Spribille T. 2011. Notes on Rinodina excrescens in the Russian Far East (Physciaceae, lichenized Ascomycota). Herzogia 24: 59-64.

Giavarini V., James P. W., Purvis $\boldsymbol{O}$. W. 2009. Rinodina (Ach.) Gray. In: Smith, C.W. et al. (eds.) The Lichens of Great Britain and Ireland. British Lichen Society and the Natural History Museum, London. 2nd edition: 812-826.

Giralt M. 2001. The lichen genera Rinodina and Rinodinella (lichenized Ascomycetes, Physciaceae) in the Iberian Peninsula. Bibliotheca Lichenologica 79: 1-160.

Giralt M. 2010. Flora Liquenológica Ibérica. Vol. 5. Physciaceae I. Endohyalina, Rinodina y Rinodinella. Barcelona: Sociedad Española de Liquenología, 105 pp.

Giralt M., Mayrhofer H. 1995. Some corticolous and lignicolous species of the genus Rinodina (lichenized Ascomycetes, Physciaceae) lacking secondary lichen compounds and vegetative propagules in Southern Europe and adjacent regions. Bibliotheca Lichenologica 57: 127-160.

Giralt M., Mayrhofer H., Obermayer W. 1994. The species of the genus Rinodina (lichenized ascomycetes, Physciaceae) containing pannarin in Eurasia with a special note on the taxonomy of Rinodina granulans. Mycotaxon 50: $47-59$.

Giralt M., Mayrhofer H., Sheard J. W. 1995. The corticolous and lignicolous sorediate, blastidiate and isidiate species of the genus Rinodina in southern Europe. Lichenologist 27(1): 3-24.

Hauck M., Javkhlan S. 2006. Additions to the lichen flora of Mongolia: records from Khentey and Khangay. Willdenowia 36: 895-912.

Hauck M., Tonsberg T., Mayrhofer H., De Bruyn U., Ochirbat E., Javkhlan S. 2013. New records of lichen species from western Mongolia. Folia Cryptogamica Estonica 50: 13-22. DOI: 10.12697/fce.2013.50.03

Helms G., Friedl T., Rambold G. 2003. Phylogenetic relationships of the Physciaceae inferred from rDNA sequence data and selected phenotypic characters. Mycologia 95: 1078-1099.

Himelbrant D. E., Stepanchikova I. S. 2011. The lichen flora of the kamchatian fir grove (Kronotsky Nature Reserve). Novosti Sist. Nizsh. Rast. [Novit. Syst. Pl. non Vasc.] 45: 150-158 [In Russian]. (Гимелбрант Д. Е., Степанчикова И. С. К лихенофлоре камчаткой пихтовой рощи (Кроноцкий заповедник) // Новости сист. низш. раст., 2011. T. 45. С. 150-158).

Insarov G. E., Pchelkin A. V. 1984. Kolichestvennie kharakteristiki sostoyanya epifitnoy likhenobioty biosfernykh zapovednikov. Sikhote-Aliskiy zapovednik [Quantitative characteristics of the state of the epiphytic lichen flora of biosphere reserves (Sikhote-Alin reserve)]. Iss. 2. VNIIMI-MTsD, Obninsk, 70 pp. [In Russian]. (Инсаров Г. Э., Пчелкин $\boldsymbol{A}$. В. Количественные характеристики состояния эпифитной лихенофлоры биосферных заповедников. Сихотэ-Алиньский заповедник. Вып. 2. Обнинск: ВНИИГМИ-МЦД, 1984. 70 с.).

Joneson S., Kashiwadani H.,Tchabanenko S., Gage S. 2004. Ramalina of the Kurile Islands. Abstracts of the $5^{\text {th }}$ symposium of the international Association for lichenology in Tartu: 26-27. 
Kaschik M. 2006. Taxonomic studies on saxicolous species of the genus Rinodina (lichenized Ascomycetes, Physciaceae) in the Southern Hemisphere with emphasis in Australia and New Zealand. Bibliotheca Lichenologica 93: $1-162$.

Kharkevich S. S. 1985. Introduction. In: Sosudistyye rasteniya sovetskogo Dalnego Vostoka [Vascular plants of the Soviet Far East]. Vol. 1. Nauka, Leningrad, 7-10 pp. [In Russian]. (Харкевич С. С. Введение // Сосудистые растения советского Дальнего Востока. Т. 1. Л.: Наука, 1985. С. 7-10).

Kondratyuk S. Y., Lökös L., Halda J. P., Morini M. H., Farkas E., Park J.-S., Lee B. G., Oh S.-O., Hur J.-S. 2016. New and noteworthy lichen-forming and lichenicolous fungi. 4. Acta Botanica Hungarica 58(1-2): 75-136. DOI: $10.1556 / 034.58 .2016 .1-2.4$

Kondratyuk S. Y., Lökös L., Tschabanenko S., Haji Moniri M., Farkas E., Wang X. Y., Oh S.-O., Hur J.-S. 2013. New and noteworthy lichen-forming and lichenologous fungi. Acta Botanica Hungarica 55(3-4): 275-349. DOI: 10.1556/ABot.55.2013.3-4.9

Kotlov Yu. V. 2008. Genus Rinodina (Ach.) Gray. In: Opredelitel lishaynikov Rossii [Handbook of the lichens of Russia]. Nauka, St. Petersburg, 10: 309-359 [In Russian]. (Котлов Ю. В. Род Rinodina (Ach.) Gray. // Определитель лишайников России. Т. 10. СПб.: Наука, 2008. С. 309-359.).

Kozhevnikov A. E., Probatova N. S. 2006. Foreword. In: Flora Rossiyskogo Dalnego Vostoka: dopolneniya $i$ izmeneniya k izdaniyu "Sosudistyye rasteniya sovetskogo Dalnego Vostoka. T. 1-8 (1985-1996)" [Flora of the Russian Far East: Additions and changes to the publication "Plantae vasculares Orientis Extremi Sovietici. Vol. 1-8 (1985-1996)”]. Dalnauka, Vladivostok, 5 p. [In Russian]. (Кожевников А. Е., Пробатова Н. С. Предисловие // Флора российского Дальнего Востока: Дополнения и изменения к изданию «Сосудистые растения советского Дальнего Востока. Т. 1-8 (1985-1996)». Владивосток: Дальнаука, 2006. С. 5).

Kurokawa S., Kashiwadani H. 2006. Checklist of Japanese Lichens and allied fungi. National Science Museum Monograph 33: 1-89.

Lendemer J. C., Tripp E. A., Sheard J. 2014. A review of Rinodina (Physciaceae) in Great Smoky Mountains National Park highlights the growing significance of this "island of biodiversity" in Eastern North America. Bryologist 117: 259-281. DOI: 10.1639/0007-2745-117.3.259

Makarova I. I., Katenin A. E. 1983. Lichens in the mountains south-east of the Chukotka Peninsula. Bot. Zhurn. (Moscow \& Leningrad) 68(11): 1477-1487 [In Russian]. (Макарова И. И., Катенин А. Е. Лишайники в горах юго-востока Чукотского полуострова // Бот. журн., 1983. Т. 68, № 11. С. 1477-1487).

Makry T. V, Tchabanenko S. I., Taran A. A. 2010. Collema complanatum (Collemataceae) is a new species for lichen flora of Russia. Bot. Zhurn. (Moscow \& St. Peterburg) 95(7): 989-991 [In Russian]. (Макрый Т. В., Чабаненко C. И., Таран A. A. Collema complanatum (Collemataceae) - новый вид для лихеофлоры России // Бот. журн., 2010. T. 95, № 7. C. 989-991).

Mayrhofer H., Moberg R. 2002. Rinodina. Nordic Lichen Flora 2: 41-69.

Nylander W. 1890. Lichenes Japoniae. Accedunt observationibus lichenes insulae Labuan. P. Schmidt, Paris, 122 pp.

Oxner A. M. 1948. Little-known and new for the USSR lichens. Botanichniy zhurnal AN USSR [Botanical Journal of the Academy of Sciences of the USSR] 5(2): 92-99 [In Ukrainian] (Окснер A. М. Маловідомі й нові для СРСР лишайники // Ботанічний журнал АН УРСР, 1948. Т. 5, № 2. С. 92-99).

Pchelkin A. V. 1987. New and interesting taxa of epiphytic lichens of the Far East. Novosti Sist. Nizsh. Rast. [Novit. Syst. Pl. non Vasc.]. 24: 166-168 [In Russian]. (Пчелкин A. В. Новые и интересные таксоны лишайниковэпифитов Дальнего Востока // Новости сист. низш. раст., 1987. Т. 24. С. 166-168).

Rodnikova I. M. 2012. The present state of lichen cover of Putjatin Island (Peter the Great Bay, Sea of Japan). Turczaninowia 15, 1: 63-69 [In Russian]. (Родникова И. М. 2012. Современное состояние лишайникового покрова острова Путятина (Залив Петра Великого, Японское море) // Turczaninowia, 2012. Т. 15, вып. 1. С. 63-69).

Rodnikova I. M. 2013. To the lichen flora of islands and mainland coast of Peter the Great Bay (Sea of Japan). Novosti Sist. Nizsh. Rast. [Novit. Syst. Pl. non Vasc.]. 47: 253-261 [In Russian]. (Родникова И. М. К лихенофлоре островов и материкового побережья залива Петра Великого (Японское море) // Новости сист. низш. раст., 2013. T. 47. C. 253-261).

Sato M. 1936. Notes on the lichen flora of Tisioma or the Kuriles. Shokubutusugaku Zasshi 50: 610-617.

Sheard J. W. 1995. Disjunct distributions of some North American, corticolous, vegetatively reproducing Rinodina species (Phyciaceae, lichenized Ascomycetes). Herzogia 11: 115-132.

Sheard J. W. 2010. The lichen genus Rinodina (Ach.) Gray (Lecanoromycetidae, Physciaceae) in North America, North of Mexico. NRC Research Press, Ottawa, 246 pp.

Sheard J. W. 2018. A synopsis and new key to the species of Rinodina (Ach.) Gray (Physciaceae, lichenized Ascomycetes) presently recognized in North America. Herzogia 31(1): 395-423. DOI: 10.13158/heia.31.1.2018.395

Sheard J. W., Ezhkin A. K., Galanina I. A., Himelbrant D. E., Kuznetsova E., Shimizu A., Stepanchikova I., Thor G., Tonsberg T., Yakovchenko L. S., Spribille T. 2017. The lichen genus Rinodina (Physciaceae, Telochistales) in northeastern Asia. The Lichenologist 49(6): 617-672. DOI:10.1017/S0024282917000536 
Sheard J. W., Knudsen K., Mayrhofer H., Morse C.A. 2011. Three new species of Rinodina and a new record from North America. Bryologist 114: 453-465. DOI: 10.2307/41289803.

Sheard J. W., Tonsberg T. 1995. Rinodina stictica, a new corticolous, sorediate lichen species from the Pacific Northwest of North America. The Bryologist 98: 41-44.

Skirina I. F. 2010. Addition to lichen flora of islands and coast of Peter the Great Bay (the Sea of Japan, Primori Territory). Novosti Sist. Nizsh. Rast. [Novit. Syst. Pl. non Vasc.]. 44: 221-236 [In Russian]. (Скирина И. Ф. Дополнение к лихенофлоре островов и прибрежных участков залива Петра Великого (Японское море, Приморский край) // Новости сист. низш. раст., 2010. Т. 44. С. 221-236).

Skirina I. F. 2012. An annotated list of lichens of Bolshekhekhtsirsky Nature Reserve (Khabarovsk Territory). Novosti Sist. Nizsh. Rast. [Novit. Syst. Pl. non Vasc.] 46: 202-216 [In Russian]. (И. Ф. Скирина. Список лишайников Большехехцирского заповедника (Хабаровский край) // Новости сист. низш. раст., 2012. Т. 46. С. 202-216).

Smith C. W., Aptroot A., Coppins B. J., Fletcher A., Gilbert O. L., Janes P. W., Wolseley P. A. 2009. The lichen of Great Britain and Ireland. British Lichen Society, London, 1046 pp.

Spribille T., Perez-Ortega S., Tonsberg T., Schirokauer D. 2010. Lichens and lichenicolous fungi of the Klondike Gold Rush National Historic Park, Alaska, in a global biodiversity context. Bryologist 113: $439-515$. DOI: 10.1639/0007-2745-113.3.439

Spribille T., Schultz M., Breuss O., Bergmeier E. 2006. Notes on the lichens and lichenicolous fungi of western Crete (Greece). Herzogia 19: 125-148.

Takhtajan A. L. 1978. Floristicheskie oblasti Zemli [Floristic regions of the Earth]. Leningrad: Nauka, 247 pp. [In Russain]. (Тахтаджян A. Л. Флористические области Земли. Л.: Наука, 1978. 248 с.).

Tchabanenko S. I. 1999. Lichens of the Kuril Reserve (Kunashir Island). In: Issledovaniye rastitelnogo pokrova rossiyskogo Dalnego Vostoka. Trudy botanicheskikh sadov DVO RAN [Study of the vegetation cover of the Russian Far East. Works of Botanical Gardens of the Far East Branch of the Russian Academy of Sciences]. Vol. 1. Dalnauka, Vladivostok, 221-228 pp. [In Russian]. (Чабаненко С. И. Лишайники Курильского заповедника (остров Кунашир) // Исследование растительного покрова российского Дальнего Востока. Труды ботанических садов ДВО РАН. Т. 1. Владивосток: Дальнаука, 1999. С. 221-228).

Tchabanenko S. I. 2002. Konspekt flori lichainikov uga Possiiskogo Dalnego Vostoka [List of the lichen flora of the Southern Russian Far East]. Dalnauka, Vladivostok, 232 pp. [In Russian]. (Чабаненко С. И. Конспект флоры лишайников юга Российского Дальнего Востока. Владивосток: Дальнаука, 2002. 232 с.)

Tchabanenko S. I. 2004. Lichens of the southern part of Sakhalin and Kuril Islands. In: Book of Abstracts, $5^{\text {th }} I A L$ Symposium, Lichens in Focus. Tartu, Estonia, 26-27 pp.

Tonsberg T. 1992. The sorediate and isidiate, corticolous, crustose lichens in Norway. Sommerfeltia 14: 1-331.

Trinkaus U., Mayrhofer H., Matzer M. 1999. Rinodina gennarii (Physciaceae), a widespread species in the temperate regions of the Southern Hemisphere. Australasian Lichenology 45: 15-21.

Urbanavichene I. N. 2010. New and rare species for lichen flora of Siberia. Novosti Sist. Nizsh. Rast. [Novit. Syst. Pl. non Vasc.] 44: 245-249 [In Russian]. (Урбанавичене И. Н. Новые и редкие виды для лихенофлоры Сибири // Новости сист. низш. раст., 2010. Т. 44. С. 245-249).

Urbanavichene I. N., Skirina I. F. 2011. Rinodina xanthophaea (Physciaceae) in Russia. Novosti Sist. Nizsh. Rast. [Novit. Syst. Pl. non Vasc.] 45: 237-241 [In Russian]. (Урбанавичене И. Н., Скирина И. Ф. Rinodina xanthophaea (Physciaceae) в России // Новости сист. низш. раст., 2011. Т. 45. С. 237-241).

Urbanavichus G. P. 2010. Spisok lichenoflory Rossii [A checklist of the lichen flora of Russia]. Nauka, St. Petersburg, 194 pp. [In Russian]. (Урбанавичюс Г. П. Список лишайников России. СПб.: Наука, 2010. 194 с.).

Vainio E. A. 1928. Enumeratio Lichenum in viciniis fluminis Konda (circ. 60u lat. bor.) in Sibiria occidentali crescentium. Annales Academiae Scientiarum Fenniae, ser. A, 27(6): 65-122.

Wirth V., Hauck M., Schultz M. 2013. Die Flechten Deutschlands. Bd. 1. Stuttgart, 513 pp. [In German].

Yakovchenko L. S., Davydov E. A., Paukov A., Frisch A., Galanina I., Han J. E., Moon K. H., Kashiwadani H. 2018. New lichen records from Korea. I. Mostly arctic-alpine and tropical species. Herzogia 31(2): 965-981. DOI: 10.13158/heia.31.2.2018.965

Yakovchenko L. S., Galanina I. A., Malashkina E. V., Bakalin V. A. 2013. Mosses and lichens in the minimally disturbed forest communities of the Lower Amur River areas (Russian Far East). Komarovskiye Chteniya [Komarovsky readings] 60: 9-66 [In Russian]. (Яковченко Л. С., Галанина И. А., Малашкина Е. В., Бакалин В. А. Мохообразные и лишайники малонарушенных лесных сообществ в Нижнем Приамурье (российский Дальний Восток) // Комаровские чтения, 2013. Вып. 60. С. 9-68).

Zhurbenko M. P. 2014. Lichenicolous fungi from Far East of Russia. Folia Cryptogamica Estonica 51: 113-119. DOI:10.12697/fce.2014.51.13 